\title{
Hospice Heuvelrug
}

\section{Glazen logo 2.0}

In en rondom hospices zijn vaak kunstwerken geplaatst. Wat voor kunst is dat en waarom is hiervoor gekozen? In de rubriek 'In het Zicht' laten we steeds zo'n kunstwerk zien, met een korte toelichting erbij

Hospice Heuvelrug in Zeist heeft een mooi, glazen kunstwerkje. Zorgvrijwilliger Ina Breedveld vertelt hoe ze het met liefde maakte. Twee keer zelfs, na een ongeluk met het eerste exemplaar. Teamleider Wilma Verkerk beschrijft welke plek het kunstwerk binnen het hospice heeft. Inmiddels staat het glazen werk onwrikbaar vast op een grafstenen voet.

\section{Drie keer in de oven}

"Ik volgde met veel enthousiasme een cursus glasin-lood”, vertelt de 78-jarige Breedveld. “Toen een verpleegkundige mij vroeg om een werk voor het hospice te maken, besloot ik iets met het logo te doen." Ina deed dit met glasfusing, een techniek waarbij meerdere lagen glas aaneen gesmolten worden in de oven. "De kleuren van het logo komen niet helemaal overeen met de huisstijl, je bent immers afhankelijk van het beschikbare glas. In de linkerbovenhoek en rechterbovenhoek heb ik daarnaast glasplaatjes aangebracht; als een beschermende omhulling. En ter markering twee glazen zwarte spaghettisliertjes. Zo is de glasplaat in drie rondes in de oven gegroeid."

\section{Eén uur later}

"We maakten er destijds een klein overhandigingsmomentje van", vertelt teamleider Verkerk. "Met een mooie foto voor de website." Breedveld onverhoeds: "En een uur later was het werk kapot!" Verkerk vertelt: "Een meneer liep de kamer van zijn vrouw uit; even de gang op. Toen hij het glazen logo zag, wilde hij de plaat omdraaien om het beter te bekijken. Omdat de plaat niet vast in de voet stond, kraakte het glas en kwam er een scheur in. Heel vervelend! Voor Breedveld die het gemaakt had, maar ook voor deze man die met zijn vrouw op sterven al zoveel aan zijn hoofd had." Breedveld: "Natuurlijk wilde ik voor het hospice een nieuwe plaat maken. Dit keer vastgelijmd op de voet."

\section{Wat het brengt}

Het hospice heeft meerdere kunstwerken die per kwartaal wisselen. Zo niet het glazen logo, dat heeft een vaste plaats op de sidetable in de gang verworven. Verkerk: "Hier komen we samen als een gast na overlijden wordt uitgedragen en staan we even stil bij het verblijf. Naast het logo brandt een kaars, die dan wordt gedoofd door de familie." Het kunstwerkje hoort bij zo'n moment en bij het hospice, vindt ze. "Ons logo staat voor individuen - gasten, naasten, zorgverleners - die los van elkaar staan, maar toch met elkaar verbonden zijn. De vormen zijn zacht en rond, je ziet dat je gedragen wordt."

Breedveld zou haar werk als vrijwilliger in het hospice niet willen missen: "Het werk en de mensen brengen mij veel. Ik ben hier een ander mens geworden.” •

Brenda van Dam is journalist.

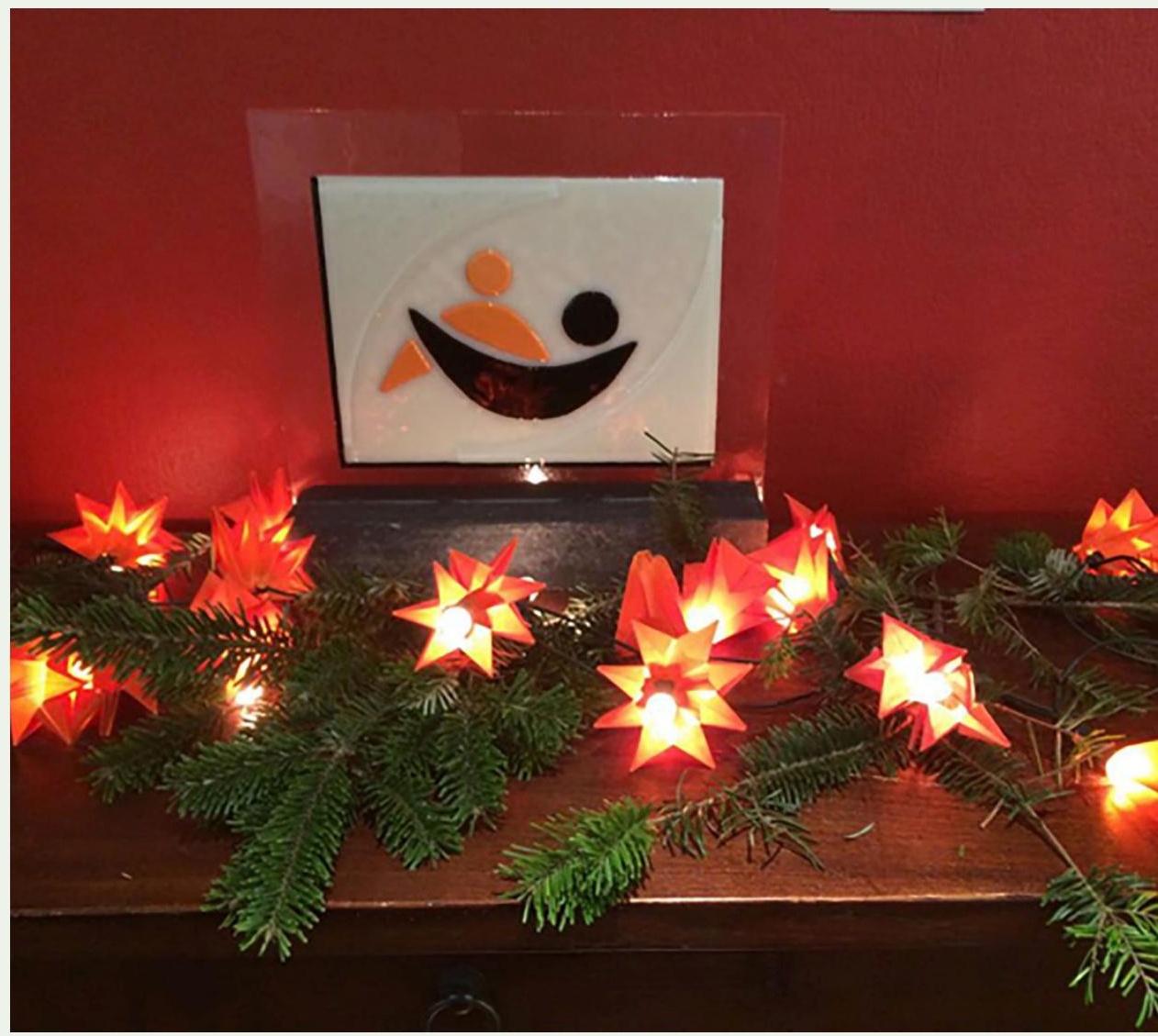

JAARGANG 20 - NUMMER 4 - SEPTEMBER 2018 